日本語版 WHO-QOL-26 の 構成妥当性の再検討

\section{折笠秀樹 ${ }^{*} 1$ 、横山奈緒美 ${ }^{*}$ 、上馬場和夫 ${ }^{*} 3$}

【目的】世界保健機関（WHO）による一般向け QOL 質問票（WHO-QOL-26 日本語版）は、1997 年に出 版された ${ }^{1}$ )。それは 4 つの領域（身体、心理、社 会、環境）から成っており、それぞれ 0 100 点 が付けられる。身体領域が 7 問、心理領域が 6 問、 社会領域が 3 問、環境領域が 8 問、全般健康度が 2 問であったが、ここでは全般健康度は検討から 除外した。妥当性の詳細については検討済みであ るが2)、その中で思うような結果が得られなかっ た構成（領域間）妥当性について、さらに詳細な 統計分析を行うことが本研究の目的である。

【方法】富山市周辺の 3 つの町（八尾・大沢野 . 婦中）に住んでいる、還暦住民への悉皆調査を用 いた二次研究である。本調査は各家庭に郵送され、 自己記入式により返送してもらった。全部で 1,013 名からアンケートを回収（回収率 65\%）し たが、QOL データがすべて揃った対象数は 805 例 であった。構成妥当性の検討には因子分析、主成 分分析、変数クラスター分析、項目反応理論、ク ロスバリデーション（2群に分け）を用いた。

【結果】 24 問、4 領域という構成が妥当かどう かについて、因子分析で検討した結果が Table 1 である。社会領域は 3 つ揃っていたが、心理領域 では 2 問（抑うつ度、自己満足度）が外れてしま っていた。さらに、環境領域でも 3 問（医療施設 の利用満足度、環境への満足度、交通の便）だけ 外れていた。また、身体領域については全く構造 が見られない状況であった。この状況はクロスバ リデーションでも同様の傾向であった。

*1 富山医科薬科大学·臨床統計学

$*_{2}$ 京都大学大学院医学系研究科・学生

*3 富山県国際伝統医学センター
混在した結果は変数クラスター分析において も同様であった。項目反応理論を用いて判別力を 見たところ（Table 2)、身体領域の 3 問（医療依 存度、移動能力、睡眠満足度)、心理領域の 1 問 （抑うつ度）は寄与が極めて低かった。環境領域 では 3 問（医療施設の利用満足度、環境への満足 度、交通の便）が低い寄与であった。因子分析で もほぼ予想のつく結果であったがはっきりした。 そこで、これらの 8 問を除いて因子分析を行うと かなり構成は明瞭になってきたが、心理領域と環 境領域が分かれなかった。これは日本人特有のこ とかもしれず、さらに考察が必要と思われた。

【結論】本質問票の構成には数々の問題点が指摘 された。また、心理と環境の領域は日本人ではそ の境界が鮮明でないことも示唆された。

\section{【文献】}

1）田崎ら：WHOQOL 短縮版-使用手引き. 東京 : 金子書房, 1997.

2）横山ら:日本語版 WHO/QOL-26 質問票の妥当性. 薬理と治療. 31(9): 737-744, 2003.

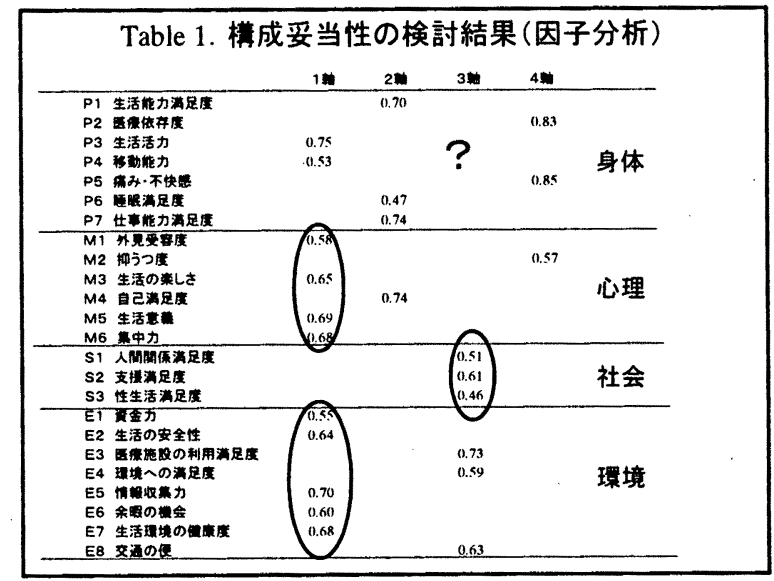

Table 2. 項目反応理論による検討(判別力)

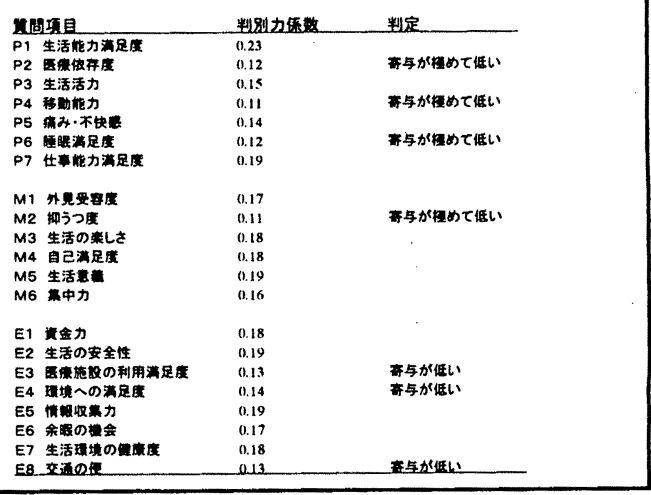

